\title{
1 Centrifuge study on effect of installation method on lateral 2 response of monopiles in sand
}

Paper submitted to International Journal of Physical Modelling in Geotechnics on 9 June 2019 by:

\section{Shengsheng Fan (corresponding author)}

PhD candidate

9 Tel: +61 (0) 864886930

10 Email: shengsheng.fan@research.uwa.edu.au

11 Orcid: http://orcid.org/0000-0002-6316-2790

12

13

14

\section{Britta Bienen}

Associate Professor

15 Tel: +61 (0) 864884246

16 Email: britta.bienen@uwa.edu.au

17 Orcid: https://orcid.org/0000-0002-0342-0698

18

19

20

\section{Mark F. Randolph}

Professor

Tel: +61 (0) 864883075

Email:mark.randolph@uwa.edu.au

Orcid: http://orcid.org/0000-0003-3136-6454

Centre for Offshore Foundation Systems

Oceans Graduate School

The University of Western Australia

35 Stirling Hwy

Crawley, Perth, WA 6009

Australia

No. of words: 5338 (excluding abstract, references and figures)

No. of tables: 4

No. of figures: 10 


\section{Abstract}

39 Monopiles used as foundations for offshore wind turbines can be installed using different

40 methods including jacking, vibratory driving and impact driving. Significant research

41 efforts have been dedicated to the characterization of monopile-soil interaction under

42 lateral loading, mainly using p-y curves. There has also been extensive research in the

43 quantifying the effect of different installation methods on the axial response using

44 numerical modelling and physical modelling techniques. Little attention has been paid to

45 the effect of the installation method on the subsequent lateral response of a monopile 46 under in-service condition. In this paper, a purpose-designed apparatus is described that 47 allows in-flight installation using different installation methods followed directly by 48 lateral loading without stopping the centrifuge and thus retaining the installation-induced 49 stress state. Test results from three lateral loading tests are discussed, with the piles either 50 jacked at $1 \mathrm{~g}$, jacked at $\mathrm{Ng}$ or impact driven at $\mathrm{Ng}$ into a dry medium dense sand, allowing 51 the effect of the installation method on the initial stiffness and ultimate capacity to be 52 examined. The successfully conducted tests illustrate the capabilities of the new apparatus 53 for centrifuge testing of laterally loaded driven piles.

54

55 Key words: Monopile; lateral response; installation effect; sand 56 


\section{INTRODUCTION}

The offshore wind energy market has been expanding rapidly due to the need for sustainable and cleaner energy sources globally. In 2017, twice as much additional net capacity as 2016 was installed, comprising 560 offshore wind turbines across 17 wind farms (EWEA, 2017). Monopiles remain the most prevalent foundation type for offshore wind turbines, accounting for $87 \%$ of all installations.

Significant research efforts have been dedicated to the characterization of monopile-soil interaction under lateral loading, mainly using p-y curves. These were originally developed for long slender small diameter piles undergoing a limited number of load cycles (API, 2011; Matlock, 1970; Reese et al., 1974). In contrast, large diameter monopiles for offshore wind turbines are of relatively low embedment (typically less than 5 diameters) and operational loading involves a high moment to load ratio, with eccentricity of several diameters. Monopiles therefore tend to behave more rigidly, and with a dominant component of rotation, so that the p-y curves developed from near surface loading of slender piles are of questionable applicability (Achmus and AbdelRahman, 2005; Achmus et al., 2009; LeBlanc et al., 2010; Zdravković et al., 2015; Byrne et al., 2015, amongst others). Moreover, monopiles are subjected to millions of load cycles over the 25-year design life, requiring the accumulated rotation and stiffness change under long-term cyclic loading to be predicted. Furthermore, the effect of pile installation on the subsequent response of monopiles under lateral loading is not accounted for, although design guidelines such as DNV (2014) acknowledge that the method of installation should be considered in the design of pile foundations. Recently, a modified p-y method has been developed as an outcome of the PISA joint industry project (Byrne et al., 2017). That study targeted monopiles and included onshore testing of driven piles subjected to monotonic push-over loading in sand and clay (with a maximum pile diameter $\mathrm{D}=2 \mathrm{~m}$ and embedded lengths $\mathrm{L} \leq 5.25 \mathrm{D}$ ). However, pile installation effects were ignored in the numerical simulations that formed the basis of the new prediction methods, which were performed as wished-in-place small strain analyses.

Research on the lateral response of monopiles has made widespread use of model tests. In the majority of published tests, the monopiles were installed by jacking at $1 \mathrm{~g}$, although 
89 it is known that the state of the surrounding soil is significantly influenced by the pile 90 installation method (Henke and Bienen, 2013; Labenski et al., 2016). As a result, the 91 subsequent lateral response of monopile may be affected. Little has been published on the 92 effect of the installation process on the subsequent lateral response of piles, although it is 93 well known that the axial response is strongly influenced by the installation method (De 94 Nicola and Randolph, 1997; Mahutka et al., 2006; Henke and Grabe, 2008; Henke and 95 Bienen, 2013). Where piles were jacked or impact driven in-flight in centrifuge tests 96 (Dyson and Randolph, 2001; Klinkvort, 2012), the tests required stopping of the 97 centrifuge to mount the lateral loading rig. Hence, the soil state following pile installation was likely changed due to the stress level changes in the soil sample. Further disturbance may have occurred when mounting the testing equipment. Hence, the effect of the pile installation process on the lateral response still holds significant uncertainty.

101

102 To address this issue, an experimental apparatus is needed that allows both in-flight 103 installation and lateral loading of monopiles without stopping the centrifuge. This paper introduces such a purpose-designed apparatus for centrifuge model tests and examines the effect of pile installation on the subsequent lateral response of monopiles. The test results allow quantification of the effect of pile installation on the initial stiffness and

107 ultimate capacity of monopiles under lateral loading and highlight the potential for using centrifuge modelling techniques for this problem.

110 In the following, all dimensions and displacements are presented at equivalent prototype 111 scale unless otherwise noted. 


\section{DEVELOPMENT OF EXPERIMENTAL LOADING APPARATUS}

114 The experiments can be divided into two phases, namely an installation phase and a

115 horizontal loading (in-service) phase. A purposed-designed apparatus which can meet the

116 test requirements has been developed, as described in the following.

118 Development of the pile driving hammer

119 Existing miniature centrifuge pile driving hammer

120 Pile installation in the centrifuge including impact driving and jacking has been achieved

121 using a purpose-built miniature pile driving hammer that is mounted on a centrifuge

122 actuator (De Nicola and Randolph, 1994; Bruno and Randolph, 1999). This apparatus

123 was also used by Henke and Bienen (2013) and Heins et al. (2018). However, it was

124 designed originally for axial loading following pile installation, without considering

125 lateral loading. Therefore, it needed to be modified for this study due to the following

126 constraints: Firstly, the pile head and driving hammer (anvil) were rigidly connected. This

127 resulted in a fixed end (zero relative rotation) boundary condition which is not

128 representative of monopiles in the field. Secondly, very limited lateral load could be

129 applied through the pile driving hammer, which would be insufficient for push-over

130 testing of monopiles.

131

132 Requirements for the modified pile driving hammer

133 In order to overcome the constraints mentioned above, modifications of the existing pile

134 driving hammer were required. The modified pile driving hammer should be capable of

135 modelling the entire pile installation process and freeing up the pile head for the lateral

136 loading stage in-flight after installation. The modified pile driving hammer therefore 137 needs to be able to:

138 (1) Suspend the pile above the soil surface during ramping up and before installation, 139 allowing installation to commence from the soil surface.

140 (2) Allow for pile penetration into the soil under its self-weight.

141 (3) Apply the installation force, through jacking or impact driving.

142 (4) Release the connection between the pile head and the pile driving hammer in-flight, 143 allowing the pile to sit freely under its self-weight. 


\section{Modifications of the pile driving hammer}

146 The pile driving hammer developed by De Nicola and Randolph (1994) was modified so

147 that the pile head could be freed after installation. Instead of a rigid threaded connection,

148 a flexible connection that could be released was used in the experiments described here.

149 Figure 1a shows the rigid connection between the pile tip and the anvil. The modified

150 connection that frees the pile head following installation is shown in Figure 1b. The anvil

151 is extended by a steel claw (item 3) and a connector (item 4) is added to the pile head.

152 The monopile hangs on the claw on the connector before initiating installation, allowing

153 the pile to be suspended above the soil surface during centrifuge spin-up. Installation is

154 effected through the compression connection once the connector is in contact with the

155 inside top of the claw. After installation, the steel claw is lifted up in-flight through

156 vertical movement of the actuator until the pile connector sits centrally in the space within

157 the claw. As a result, clearance of around $8 \mathrm{~mm}$ is created at both top and bottom of the

158 connector head, which is sufficient to release any constraint on the pile head. Details of 159 the connection are shown in Figure 1c.

160

161 Development of the lateral loading rig

\section{Requirements for the new lateral loading rig}

163 Monopile lateral loading tests have been conducted using different experimental 164 arrangements (Dyson and Randolph, 2001; Klinkvort, 2012; Bienen et al., 2012).

165 However, these tests required stopping of the centrifuge to mount the lateral loading rig.

166 As a result, the soil state was likely changed. In order to maintain the stress states induced

167 by pile installation, the lateral loading should be applied without stopping the centrifuge.

168

169 Monopiles for offshore wind turbines are subjected to complex wind, wave and current 170 loads from the ocean environment. This requires a facility for cyclic load application, 171 although monotonic lateral load was considered for this first series of tests to obtain the 172 full load-displacement curve to ultimate capacity, allowing changes in stiffness to be 173 evaluated as well. 
175 In the absence of a multi-tool in-flight robot (Gaudicheau et al, 2014), in order to allow

176 lateral loading to be carried out directly following installation the loading device needs 177 to:

178 (1) be mounted on the actuator from the start, i.e. in-place before pile driving;

179 (2) not disturb the pile installation process; and

180 (3) allow both monotonic and cyclic loading.

181

\section{Details of the lateral loading rig}

183 A loading yoke similar to that used by Dyson and Randolph (2001) and Bienen et al. 184 (2012) was manufactured to meet the aforementioned requirements, as shown in Figure 185 2. In previous work, the loading yoke was mounted on the actuator carriage. This was not 186 possible here, as the vertical degree-of-freedom of the actuator was used solely for pile 187 installation and any use during the lateral loading phase would have conflicted with the 188 pile movement. The loading rig, consisting of a free head loading yoke and a connection 189 piece (Figure 2), was therefore mounted on the bottom plate of the actuator as shown in 190 Figure 3.

191

192 This configuration increases significantly the magnitude of lateral load that can be applied 193 as all the loads are taken by the horizontal lead screw rather than being transferred through 194 the pile driving hammer. More importantly, the loading rig can be mounted in-place 195 initially without influencing the pile installation, and also acts as an installation guide. 196 The internal diameter of the loading yoke is slightly larger than the pile diameter to 197 accommodate slight imperfections in the pile outer diameter or roundness. The size of the 198 pile necessitates a relatively large and thus heavy loading yoke. Therefore, a pair of 199 miniature linear bearings (as shown in Figure 2b) was attached to the bottom plate of the 200 actuator to support the connection piece, thus eliminating any effect of the yoke self201 weight on the accuracy of the lateral force measurement. The loading yoke can move 202 freely on the linear guides. The general arrangement of the complete apparatus is shown 203 in Figure 3. 
205 Instrumentation of the experimental apparatus

206 Load measurements

207 The driving force was measured using a $10 \mathrm{kN}$ load cell connected to the pile cap (see

208 Figure 1 and Figure 3). The jacking force was obtained directly from the load cell reading

209 recorded by the data acquisition system (DIGDAQ). A high-frequency sampling rate is

210 required to capture the transient peak driving force during impact driving (Bruno and

211 Randolph, 1999). This is only achievable for a limited number of blows as the data file

212 becomes extremely large and the logging system can become unstable. Therefore, the

213 transient peak impact force was measured in a calibration test conducted to check the

214 hammer driving efficiency (see results section) but not during the centrifuge tests.

215

216 The lateral load was measured using a $3 \mathrm{kN}$ load cell connected to the loading yoke (see

217 Figure 2 and Figure 3).

218

219

\section{Displacement measurements}

220 During the installation phase, the pile displacement can be derived from the vertical actuator motor encoder. This allows the embedment length to be calculated. During the lateral loading phase, the lateral displacements at two elevations were measured with two laser displacement sensors (KEYENCE LB-11). Determination of pile head displacement and rotation from these measurements is discussed in the results section.

\section{Limitations of the loading apparatus}

227 The apparatus meets the requirements stated earlier in this paper. However, some 228 limitations still remain:

229 1. The maximum achievable jacking force is around $7.0 \mathrm{kN}$, which is constrained by 230 the integrity of the actuator and the pile driving hammer.

2312 2. The maximum achievable impact driving force is currently around $25 \mathrm{MN}$ (2.5 kN 232 in model scale). This is constrained by the size of the hammer, including the drop 233 height and ram weight.

234 3. The maximum pile driving frequency is limited to $15 \mathrm{~Hz}$ (in model scale). 
236 Modification of these specifications would require a new miniature pile driving hammer 237 to be designed and built. As a consequence, jacked and driven installation into dense sand 238 may result in limited embedment depth due to the high penetration resistance. 
MODEL TEST

\section{Facility}

242 The experiments were conducted in the 10-meter diameter beam geotechnical centrifuge

243 (C72 Centrifuge) at the National Geotechnical Centrifuge Facility (NGCF), hosted by

244 Centre for Offshore Foundation Systems at the University of Western Australia

245 (Randolph and Gaudin, 2017). An acceleration of 100g was defined at 2/3 of the initial

246 target embedment length $(250 \mathrm{~mm})$ from the soil surface.

\section{Test arrangement}

249 All tests were conducted in a strong box with internal dimensions of $1000 \mathrm{~mm} \times 1000$ $250 \mathrm{~mm}$ in plan and $478 \mathrm{~mm}$ deep. A side view of the lateral loading test layout (post installation) is shown in Figure 4. The pile is shown schematically, with details given later. The embedment length (L) and the load eccentricity (e) were maintained the same for all tests, allowing the test results to be compared directly. The displacement sensors were mounted on a bracket attached to a cross beam (items 11, 12 in Figure 3).

\section{Model monopile and instrumentation}

257 Details of the model monopile are shown in Figure 5. The steel monopile has an outer 258 diameter (D) of $50 \mathrm{~mm}$ and a wall thickness (t) of $1.0 \mathrm{~mm}$. The corresponding diameter 259 to wall thickness ratio (D/t) is 50 . This represents a prototype monopile with a diameter 260 of $5.0 \mathrm{~m}$ and a wall thickness of $0.1 \mathrm{~m}$ when tested at $100 \mathrm{~g}$. The total length of the pile is $261500 \mathrm{~mm}$ (10D). The dimensions of the model monopile are similar to monopiles used in 262 field conditions (Byrne et al., 2015), although the D/t ratio of the steel itself is slightly 263 higher. The model pile is made from a welded pipe using V2A-steel (material number 264 1.4301). It has a proof stress of around $200 \mathrm{MPa}\left(\mathrm{RP}_{0.2}=190 \mathrm{MPa} ; \mathrm{RP}_{1.0}=225 \mathrm{MPa}\right)$, 265 according to European standard DIN EN 10088-3. The Young's modulus is around 200 266 GPa. Standard high strength steel tubes or alloy pipes available with the specified 267 diameter tend to have a larger wall thickness. These were deemed unsuitable for this study 268 as a larger wall thickness pile would lead to a higher penetration resistance, and not reflect typical pile-soil stiffness ratios under lateral loading. 
271 Ten pairs of full bridge strain gauges (Dual Parallel Grids Strain Gage, SGT-3/350-DY41)

272

273

274

275

276

277

278

279

280

281

282

283

284

285

286

287

288

289

290

291

292

293

294

295

296

297

298

299

300

301 were attached to the pile external surface to measure the bending moment, with gauge locations shown in Figure 5. The gauges and wires are protected by a $1.1 \mathrm{~mm}\left(\mathrm{t}_{1}\right)$ thick layer of epoxy coating as the full testing program includes experiments in saturated sand. The epoxy coating leads to an increase in the wall thickness. As a result, the overall pile diameter $\left(\mathrm{D}_{\text {pile }}=\mathrm{D}+2 \mathrm{t}_{1}\right)$ and wall thickness $\left(\mathrm{T}=\mathrm{t}+\mathrm{t}_{1}\right)$ are $52.2 \mathrm{~mm}$ and $2.1 \mathrm{~mm}$ respectively. This actually has a beneficial effect of increasing the effective $D_{\text {pile/t }}$ ratio to 60 , which is more typical of monopiles near the seabed surface; note that Young's modulus of the epoxy is much lower than for steel so that it has a negligible effect on the pile bending stiffness.

The roughness of the external epoxy surface and the internal pile steel surface (mill finished) was $0.80 \mu \mathrm{m}$ and $0.31 \mu \mathrm{m}$, respectively. The normalised surface roughness is in the range 0.0016 to 0.0042 . The pile is smoother than a standard offshore pile, for which the normalised surface roughness lies typically in the range 0.02 to 0.03 (De Nicola and Randolph, 1997).

\section{Soil preparation and characterisation}

All tests were conducted in dry, very fine UWA silica sand with properties summarized in Table 1 . The pile diameter to mean grain size ratio $\mathrm{D} / \mathrm{d}_{50}$ is 278 . The effect of particle size can be neglected if $\mathrm{D} / \mathrm{d}_{50}$ is larger than 60-100 (Dyson and Randolph, 2001; Verdure et al., 2003). A 'modelling of model' study conducted by Klinkvort and Hededal (2010) suggests a ratio of the pile diameter and mean particles greater than 105 is sufficient to minimize scale effect for short stiff piles. Ideally the ratio of wall thickness to mean particle size $\mathrm{t} / \mathrm{d}_{50}$ should be larger than 10 (De Nicola, 1996; De Nicola and Randolph 1997) to avoid particle size effect on the interaction between the pile annulus and the soil. However, the wall thickness of the model pile is only 1\% prototype size, which makes it impractical to meet the given criterion exactly. Therefore, a balance was struck between maintaining geometry similitude and avoiding potential particle size effect, resulting in a ratio of pile annulus to mean particles size of 5.6. Tran (2005) showed that variations in the absolute wall thickness of a suction caisson did not affect the installation response 
302

303

304

305

306

307

308

309

310

311 The sample was calibrated by in-flight cone penetration tests (CPTs) using a $7 \mathrm{~mm}$

312 diameter miniature cone penetrometer. The cone (tip) resistance profiles are shown in

313 Figure 6. The relative density was evaluated according to the correlation of relative

314 density with cone resistance after Schneider and Lehane (2006). The estimated relative

315 density is $D_{R}=38 \pm 4 \%$.

316

317

318

319

320

321

322

323

324

325

326

327

328

330

331

332

significantly. Thus the effect of the wall thickness on the pile installation is judged to be minor in this study.

A medium dense sand sample was used to minimise the penetration resistance in the tests discussed in this paper. The sample was prepared loose by pouring the sand into the strongbox carefully by hand with a scoop at the minimum dropping height. Following transferral to the centrifuge basket, the sample was spun up and down several times to limit further densification over the course of the testing program.$$
\text { density is } \mathrm{D}=38 \pm 4 \% \text {. }
$$

\section{Test program and procedure}

\section{Pile installation}

The monopile was installed in-flight through jacking or impact driving using the modified pile driving hammer. A test featuring jacked installation at $1 \mathrm{~g}$ was conducted for comparison. The jacked installation was performed by applying a constant penetration rate of $0.5 \mathrm{~mm} / \mathrm{s}$ through the pile driving hammer and actuator. A ram weight of $0.05 \mathrm{~kg}$ and drop height of $17 \mathrm{~mm}$, in model scale, was used for the impact driving test. This corresponds to a ram weight of $50 \mathrm{t}$ and drop height of $1.7 \mathrm{~m}$ in prototype scale when tested at 100g. The driving frequency was $5 \mathrm{~Hz}$ (model scale).

The maximum penetration resistance was expected for the jacked installation at Ng. The jacked installation was stopped when the penetration resistance approached the actuator capacity. A penetration of $15.9 \mathrm{~m}\left(\mathrm{~L} \approx 3.1 \mathrm{D}_{\text {pile}}\right)$ was achieved. The embedment length in the $1 \mathrm{~g}$ jacked installation and $\mathrm{Ng}$ impact driving tests was maintained the same to enable direct comparison of the response under lateral loading. 
333

334

335

336

337

338

339

340

341

342

343

344

345

346

347

348

349

350

351

352

353

354

355

356

357

358

359

360

361

362

\section{Pile lateral loading}

After installation, the pile head was released as described earlier and the quasi-static monotonic lateral loading was applied using the loading yoke until the monopile mudline

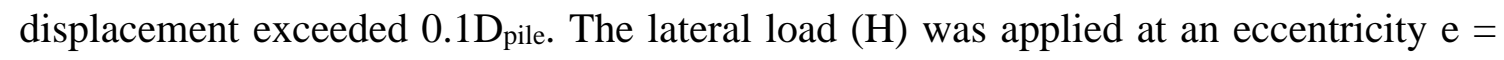
$3.8 \mathrm{D}_{\text {pile }}$ above the soil surface. The resulting bending moment at mudline is $\mathrm{M}=\mathrm{He}$.

\section{Test procedure details}

The experiments were performed according to the following procedure:

- The pile was supported on the steel claw while the centrifuge ramped up to the target acceleration level. The pile was suspended just above the soil surface until installation was initiated.

- The pile penetrated into the soil under its self-weight. This was achieved by requesting the vertical actuator to travel downwards slowly (at a rate of $0.1 \mathrm{~mm} / \mathrm{s}$ ).

- The procedures for jacked installation and impact driving are slightly different.

a) Jacked installation: As the assembly continued to move, the additional weight of the steel claw (anvil) and the ram were transferred gradually to the pile, resulting in further penetration. Once the ram had lifted to reach the inside top of the casing (gap 2 closed, Figure 3a), the compression connection was established and the constant displacement rate of the actuator was transferred to the pile. Pile jacking was terminated as the driving resistance approached the actuator capacity.

b) Impact driving: The pile driving hammer continued to move until the anvil was elevated by a distance (clearance) of around $3 \mathrm{~mm}$. The pile driving hammer was activated and impact driving started. The control system allows the vertical actuator to follow the penetrating pile, maintaining the specified impact drop height, using the displacement transducer within the pile driving hammer. The driving process was stopped when the same penetration depth as the Ng jacked installation was achieved.

- After installation, the steel claw was lifted up by the pile driving hammer by moving the vertical actuator upwards. This created the required clearance around the pile head connector for the lateral loading phase. 
363

364

365

366

367

368

369

370

371

372

- The lateral loading was then applied through the loading yoke. This was achieved by moving the horizontal actuator at a controlled rate of $0.01 \mathrm{~mm} / \mathrm{s}$. This is sufficiently slow to ensure a quasi-static pile response.

All operations including the pile installation and the lateral loading were performed without stopping the centrifuge. For comparison, a test featuring jacked installation at $1 \mathrm{~g}$ was included (using the same procedure as in the Ng jacked installation but ramping the centrifuge up only for the lateral loading phase, the main difference being the stress level during installation). A summary of tests conducted is given in Table 2. 


\section{EXPERIMENTAL RESULTS AND DISCUSSIONS}

\section{Pile installation history}

\section{Jacked installation}

376 Figure 7 presents the penetration resistance reported during $1 \mathrm{~g}$ and $\mathrm{Ng}$ jacked installation.

377 The penetration depth is normalised by the overall pile diameter ( $\left.\mathrm{D}_{\text {pile }}\right)$. The jacking force 378 and impact driving force discussed in the following are normalised as stress by dividing 379 the force by the gross cross-sectional area (A). The penetration resistance reported is the 380 sum of the tip resistance and the shaft resistance. A penetration of $15.9 \mathrm{~m}$ in prototype scale (159 mm in model scale, $\mathrm{L}=3.1 \mathrm{D}_{\text {pile }}$ ) was achieved. A significant difference is observed when comparing the results of piles jacked at $1 \mathrm{~g}$ and $\mathrm{Ng}$, with the jacking force required for in-flight installation around 40 times higher than that in the $1 \mathrm{~g}$ jacked installation. Similar results were reported by Haffar et al. (2017), where the effect of the stress level on the response of pile installation was investigated. The axial capacity of the piles was estimated using the UWA-05 method (Lehane et al., 2005), resulting in a value (normalised by A) of around 2.2 MPa. However, this should be considered a lower bound on the expected capacity, since the method is aimed at driven piles, where the cyclic nature of the installation process will give much greater friction degradation than for a jacked pile. Indeed, the measured bearing capacity is $3.1 \mathrm{MPa}$, which is $43.9 \%$ higher.

Although no direct observation of the internal soil plug was possible in the experimental setup, the penetration resistance may be used to gauge the degree of plugging during jacking. Assuming a shaft friction ratio of $1 \%$ of the cone resistance, the total predicted shaft resistance (internal and external) would only be around V/A $1 \mathrm{MPa}$, while the annular tip resistance (assuming full qc mobilised) would be 1.2 MPa. If plugging occurs the internal shaft resistance will rise because of arching effects, although will ultimately be limited by the plugged end-bearing resistance, which may be estimated as $\sim 0.6^{*} \mathrm{q}_{\mathrm{c}}=$ 4.8 MPa. The measured penetration resistance of 3.1 MPa therefore suggests that full plugging did not occur, but partial plugging must have started.

401

402

\section{Impact driving}

403 Figure 8a shows the self-weight penetration and cumulative hammer blows recorded 
405

406

407

408

409

410

411

412

413

414

415

416

417

418

419

420

421

422

423

424

425

426

427

428

429

430

431

432

433

434

435

436

weight before being driven. It took 1,977 blows to drive the pile to the same embedment length as the jacked installation. The number of blows required per unit penetration increases with the penetration depth, as expected. A driving speed of around 27 blows $/ \mathrm{m}$ was recorded at shallow depths and around 330 blows/m was reported at the end of the driving, both of which are realistic for prototype conditions.

Figure 8b shows a typical transient impact driving force obtained during trial tests. This is very similar to those reported by Bruno and Randolph (1999) and Heins et al. (2018). A peak impact force of around 1.2 MPa was recorded, with two successive peaks observed in each strike. This probably reflects a slight bounce between the pile cap and anvil.

\section{Pile under monotonic lateral loading}

\section{Determination of pile head displacement and rotation}

The pile head displacement and rotation (defined at the mudline) are normally used as design criteria in design codes such as DNV (2014). However, displacement measurement directly at the mudline was not feasible due to the difficulty in arranging transducers in a centrifuge test. Instead, the pile displacements were measured at two elevations, $22 \mathrm{~mm}$ (0.44D) and $126 \mathrm{~mm}$ (2.52D) above the mudline (Figure 4). The pile head displacement and rotation may then be derived using rigid beam theory or, slightly more accurately, using Euler-Bernoulli or Timoshenko beam theories that account for pile deformation.

Both laser displacement transducers and linear potentiometers have been used in the literature and were trialled in this study. Measuring accuracy of less than $5 \mu \mathrm{m}$ is required to capture the small displacement response reasonably well, especially during cyclic loading, but a significant displacement range is needed for ultimate capacity. The potentiometers did not perform well due to the excessive transverse forces, and hence friction, when used to measure lateral displacements perpendicular to the high g field. Contact between the pile and transducer may also result in additional frictional force when the pile penetrates. Therefore, two non-contact laser displacement sensors were used in the tests, allowing displacements and rotations at mudline to be derived. 
437 The displacement profiles allowing for pile deformation can be written as

438

439

440

441

442

443

444

445

446

447

448

449

450

451

452

453

454

455

456

457

458

459

460

461

462

463

464

465

466

467

468
(1) $\delta=\frac{H}{6 E I} z^{2}(3 e-z)$

(2) $\delta=\frac{\mathrm{H}}{6 \mathrm{EI}} \mathrm{z}^{2}(3 \mathrm{e}-\mathrm{z})+\frac{\mathrm{Fz}}{\mathrm{KAG}}$

where $\mathrm{H}$ the lateral force applied, $\mathrm{z}$ the distance above mudline, e the load eccentricity, EI the pile bending stiffness, A the pile cross sectional area, $G$ the pile shear modulus and $\kappa$ the Timoshenko shear coefficient, with $\kappa=0.90$ for a pipe pile (Faghidian, 2017).

The results of pile head displacement obtained for the different beam theories are indistinguishable as shown in Figure 9. The lateral displacement is normalised by the pile external diameter $\left(D_{\text {pile}}\right)$. The lateral force is normalised by $\gamma^{*} D_{\text {pile }}{ }^{3}, \gamma$ is the unit weight of the sand (see Table 2). This indicates that the pile tends to behave as rigid over the relevant length $\left(\mathrm{z}_{2}=2.52 \mathrm{D}\right)$ and rigid beam theory was therefore used to determine the mudline displacement and rotation throughout.

\section{Effect of pile installation method on the initial stiffness and ultimate capacity}

Figure 10 shows the lateral response of monopiles installed by different installation methods. Both qualitative and quantitative comparisons are made. The lateral capacity mobilised at $0.1 \mathrm{D}_{\text {pile }}$ mudline displacement is summarised in Table 3 . The initial stiffness (kini) defined as the tangential stiffness at zero mudline displacement is summarized in Table 4 . The secant stiffness (kult) defined at $0.1 \mathrm{D}_{\text {pile }}$ mudline displacement is also given in Table 4. Only normalised values are given in Table 3 and 4.

The model pile jacked in-flight shows larger initial stiffness than when jacked at $1 \mathrm{~g}$ due to retention of high lateral stresses caused by installation. This is in agreement with the findings given in Dyson and Randolph (2001) and Klinkvort (2012). However, trend of the two curves in Figure 10 suggests that the stress level effect may ultimately be erased, although this would require large pile head displacement (much greater than $0.2 \mathrm{D}_{\text {pile) }}$ ) In contrast, a pile installed using impact driving shows larger initial stiffness and higher ultimate capacity than the jacked piles. Although the ambient stress levels were identical in tests where the piles were jacked or driven at $\mathrm{Ng}$, the increased stiffness and ultimate capacity result from changes in soil state caused by impact driving. According to the numerical investigation by Henke and Grabe (2008), the external horizontal stress in the vicinity of the pile tip is much higher following jacking than following impact driving in 
469

470

471

472

473

474

475

476

477

478

479

480

481

482

483

484

485

486

487

488

489

490

491

492

493

494

495

496

497

498

a medium dense sand sample with a relative density of 51\%-55\%. Higher vertical stress near the pile tip is also expected following jacking than following impact driving. However, the degree of densification of soil, especially in the upper part of pile is higher following impact driving than following jacking. In addition, a relative looser sample with a relative density of $38 \pm 4 \%$ was used in this study and thus the degree of densification was judged to be higher. This could be a reasonable explanation that impact driven pile has a higher lateral initial stiffness and ultimate capacity. A stiffer axial response of impact driving piles than jacked piles was also reported by Heins et al. (2018) due to the densification of surrounding soil caused by impact driving in a sand sample with a similar relative density.

The impact driven pile has a normalised ultimate capacity of 3.4, which is $15 \%$ higher than for the jacked pile (2.9) as shown in Figure 10. The normalised initial stiffness of the impact driven pile is 567.3, which is $60 \%$ higher than for the jacked pile (354.4). The results suggest the foundation stiffness is significantly influenced by the installation method. Offshore wind turbines are dynamically sensitive structures. Further research to characterise this influence on monopile response under cyclic lateral loading is currently ongoing.

The fatigue and serviceability limit states (FLS and SLS) are key design drivers for offshore monopile foundations, with accurate estimation of the structural natural frequency being particularly important for the FLS design (Arany et al., 2015). The system natural frequency of offshore wind turbines is influenced by the foundation stiffness. Therefore changes in soil state due to the installation process should be considered in the design as they will affect the natural frequency of the foundation. To illustrate this point, using the method given in Arany et al. (2016), the natural frequency for Burbo Bank Offshore Wind Farm (considered here because the seabed also comprises sandy soil) would increase by $4.2 \%$ if the foundation stiffness was increased by $60 \%$; or alternatively it would decrease by $13.8 \%$ if the foundation stiffness was reduced by $60 \%$. 
499

500

501

502

503

504

505

506

507

508

509

510

511

512

513

514

515

516

517

518

519

520

521

522

523

524

525

526

527

528

529

530

\section{CONCLUSIONS}

This paper has detailed the development of a purpose-designed apparatus that allows inflight pile installation using different installation methods, followed directly by lateral loading without stopping the centrifuge, hence retaining the installation-induced stress state in the soil. All operations can be conducted in-flight and this is one of the few reported centrifuge test series where this is possible. This is deemed particularly important as ramping up and down the centrifuge or any manipulation would change the soil state around the pile. The apparatus makes it possible to replicate field operations including pile installation from the soil surface and lateral loading in a centrifuge.

The results of three lateral loading tests where model monopiles were jacked at 1g, jacked at $\mathrm{Ng}$ and impact driven at Ng into a dry medium dense sand sample were analysed. The following conclusions are drawn from the test results.

- The axial force required to jack the pile to a penetration of 3.1 diameters was $44 \%$ higher than would be estimated using the UWA-05 method for driven piles. This suggests higher (average) radial effective stresses around the pile shaft and at the base, i.e. with less friction degradation that accompanies the cyclic shearing that occurs during driving.

- The initial stiffness and ultimate capacity of a monopile under lateral loading in a medium dense sand are significantly influenced by the installation process. The impact driven pile shows both higher initial stiffness and larger ultimate capacity than the jacked pile. The stress level effect was also demonstrated through comparison of piles jacked at $1 \mathrm{~g}$ and $\mathrm{Ng}$, with the latter showing increased stiffness and capacity under lateral loading, as expected.

- The higher stiffness and capacity for the driven pile compared with the jacked pile (both at $\mathrm{Ng}$ ) may be attributed to increased density of the sand following driving.

- As a result of changes in soil state, the installation method will affect the natural frequency of an offshore wind turbine founded on a monopile. In turn, this will influence the FLS design of offshore wind turbines.

Further research on the effect of the installation process on the in-service response of monopiles are ongoing. Factors such as pore fluid response (saturated sand) and the effect 
531 of cyclic loading at working load levels are considered. The test results will also be used 532 to validate numerical models, which will be used to extend the research to dense sands 533 and a wider range of pile diameter, wall thickness and embedment length.

534 


\section{ACKNOWLEDGEMENTS}

536 This work forms part of the activities of the Centre for Offshore Foundation Systems 537 (COFS), which is currently supported as a Centre of Excellence by the Lloyd's Register 538 Foundation and through the Fugro Chair in Geotechnics and the Shell EMI Chair in 539 Offshore Engineering. Lloyd's Register Foundation helps to protect life and property by 540 supporting engineering-related education, public engagement and the application of 541 research. This support is gratefully acknowledged. Further, support from the technical 542 staff (John Breen, Manuel Palacios, Adam Stubbs, David Jones, Khin Seint, Mike Turner, 543 Andrew Van Dam and Guido Wager) at the National Geotechnical Centrifuge Facility 544 (NGCF) is gratefully acknowledged.

545 


\section{NOTATIONS}

\begin{tabular}{|c|c|c|}
\hline A & {$\left[\mathrm{m}^{2}\right]$} & Pile total (gross) cross sectional area, $\pi \mathrm{D}_{\text {pile }}^{2} / 4$ \\
\hline $\mathrm{d}_{50}$ & {$[\mathrm{~mm}]$} & mean grain/particle size \\
\hline $\mathrm{D}$ & {$[\mathrm{m}]$} & pile outer diameter (steel) \\
\hline $\mathrm{D}_{\text {pile }}$ & {$[\mathrm{m}]$} & overall pile diameter (including epoxy) \\
\hline $\mathrm{DR}_{\mathrm{R}}$ & {$[-]$} & relative density of sand \\
\hline e & {$[\mathrm{m}]$} & load eccentricity \\
\hline EI & {$\left[\mathrm{Nm}^{2}\right]$} & bending stiffness \\
\hline G & [GPa] & shear modulus \\
\hline $\mathrm{H}$ & {$[\mathrm{N}]$} & lateral load \\
\hline$k_{\text {ini }}$ & {$[\mathrm{MN} / \mathrm{m}]$} & initial stiffness \\
\hline kult & {$[\mathrm{MN} / \mathrm{m}]$} & secant stiffness \\
\hline $\mathrm{L}$ & {$[\mathrm{m}]$} & pile embedment length \\
\hline M & {$[\mathrm{Nm}]$} & bending moment \\
\hline $\mathrm{N}$ & {$[-]$} & g level \\
\hline $\mathrm{RP}_{0.2}$ & {$[\mathrm{MPa}]$} & proof stress at $0.2 \%$ plastic strain \\
\hline $\mathrm{RP}_{1.0}$ & {$[\mathrm{MPa}]$} & proof stress at $1.0 \%$ plastic strain \\
\hline $\mathrm{t}$ & {$[\mathrm{m}]$} & pile wall thickness \\
\hline $\mathrm{t}_{1}$ & {$[\mathrm{~m}]$} & epoxy coating thickness \\
\hline $\mathrm{T}$ & [m] & overall pile wall thickness (including epoxy) \\
\hline $\mathrm{U}$ & {$[-]$} & index of uniformity \\
\hline $\mathrm{z}$ & [m] & distance above mudline \\
\hline $\mathrm{Z} 1$ & [m] & distance above mudline (laser 1 ) \\
\hline $\mathrm{Z} 2$ & [m] & distance above mudline (laser 2) \\
\hline$\delta$ & {$[\mathrm{m}]$} & pile deflection \\
\hline$\gamma$ & {$[\mathrm{kN} / \mathrm{m} 3]$} & sample dry density \\
\hline$\gamma_{\mathrm{d} \max }$ & {$[\mathrm{kN} / \mathrm{m} 3]$} & maximum dry density \\
\hline$\gamma_{\mathrm{d} \text { min }}$ & {$[\mathrm{kN} / \mathrm{m} 3]$} & minimum dry density \\
\hline$\kappa$ & {$[-]$} & Timoshenko shear coefficient \\
\hline
\end{tabular}


548

549

550

551

552

553

554

555

556

557

558

559

560

561

562

563

564

565

566

567

568

569

570

571

572

573

574

575

576

577

578

\section{REFERENCES}

Achmus, M. \& Abdel-Rahman, K., (2005). Finite element modelling of horizontally loaded monopile foundations for offshore wind energy converters in Germany. Frontiers in Offshore Geotechnics. http://dx.doi.org/10.1201/noe0415390637.ch38.

Achmus, M., Kuo, Y. S. \& Abdel-Rahman, K., (2009). Behavior of monopile foundations under cyclic lateral load. Computers and Geotechnics, 36(5), pp.725-735. http://dx.doi.org/10.1016/j.compgeo.2008.12.003.

API (American Petroleum Institute). (2011). Recommended practice 2GEO Geotechnical and Foundation Design Considerations, 1st Edition. Washington, DC, USA: API.

Arany, L., Bhattacharya, S., Macdonald, J. H. G., \& Hogan, S. J. (2015). A critical review of serviceability limit state requirements for monopile foundations of offshore wind turbines. Offshore Technology Conference. http://dx.doi.org/10.4043/25874-ms.

Arany, L., Bhattacharya, S., Macdonald, J. H. G., \& Hogan, S. J. (2016). Closed form solution of Eigen frequency of monopile supported offshore wind turbines in deeper waters incorporating stiffness of substructure and SSI. Soil Dynamics and Earthquake Engineering, 83, 18-32. http://dx.doi.org/10.1016/j.soildyn.2015.12.011.

Bienen, B., Dührkop, J., Grabe, J., Randolph, M. F., \& White, D. J. (2012) . Response of piles with wings to monotonic and cyclic lateral loading in sand. Journal of Geotechnical and Geoenvironmental Engineering, 138(3), pp.364-375. http://dx.doi.org/10.1061/(asce)gt.1943-5606.0000592.

Byrne, B.W., McAdam, R., Burd, H.J., Houlsby, G., Martin, C., Zdravković, L., Taborda, D.M.G., Potts, D.M., Jardine, R.J., Sideri, M. \& Schroeder, F.C., (2015). New design methods for large diameter piles under lateral loading for offshore wind applications. In 3rd International Symposium on Frontiers in Offshore Geotechnics (ISFOG 2015), Oslo, Norway, pp. 10-12. http://dx.doi.org/10.1201/b18442-96.

Byrne, B.W., McAdam, R.A., Burd, H., Houlsby, G.T., Martin, C.M., Beuckelaers, W.J.A.P., Zdravkovic, L., Taborda, D.M.G., Potts, D.M., Jardine, R.J. and Ushev, E., (2017). PISA: New design methods for offshore wind turbine monopiles. Offshore Site Investigation Geotechnics 8th International Conference Proceedings, pp.142161. http://dx.doi.org/10.3723/osig17.142. 
579

580

581

582

583

584

585

586

587

588

589

590

591

592

593

594

595

596

597

598

599

600

601

602

603

604

605

606

607

608

609

610

Bruno, D. \& Randolph, M.F., (1999). Dynamic and static load testing of model piles driven into dense sand. Journal of Geotechnical and Geoenvironmental Engineering, 125(11), pp.988-998. http://dx.doi.org/10.1061/(asce)1090-0241(1999)125:11(988).

De Nicola, A., (1996). The performance of pipe piles in sand (Doctoral dissertation, University of Western Australia).

De Nicola, A. \& Randolph, M.F., (1994). Development of a miniature pile driving actuator. In Proc. Int. Conference Centrifuge. 94, pp. 473-478.

De Nicola, A. \& Randolph, M.F., (1997). The plugging behaviour of driven and jacked piles in sand. Géotechnique, 47(4), pp. 841-856. http://dx.doi.org/10.1680/geot.1997.47.4.841.

DIN EN 10088-3, (2014). Stainless steels - Part 3: technical delivery conditions for semifinished products, bars, rods, wire, sections and bright products of corrosion resisting steels for general purposes. Berlin.

DNV (Det Norske Veritas) (2014). Offshore standard DNV-OS-J101 - Design of offshore wind turbine structures. Hoevik, Norway: DNV.

Dyson, G.J. \& Randolph, M.F., (2001). Monotonic Lateral Loading of piles in calcareous sand. Journal of Geotechnical and Geoenvironmental Engineering, 127(4), pp.346352. http://dx.doi.org/10.1061/(asce)1090-0241(2001)127:4(346).

EWEA (European Wind Energy Association) (2017). Offshore Wind in Europe - Key trends and statistics 2017. Brussels, Belgium: European Wind Energy Association.

Faghidian, S. A., (2017). Unified formulations of the shear coefficients in timoshenko beam theory. Journal of Engineering Mechanics, 143(9), p.06017013. http://dx.doi.org/10.1061/(asce)em.1943-7889.0001297.

Gaudicheau, P., Thorel, L., Néel, A., Audrain, P., Lozada, C. \& Monroy, J., (2013). Improvement of the IFSTTAR robot control system. ICPMG2014 - Physical Modelling in Geotechnics, pp.221-226. http://dx.doi.org/10.1201/b16200-24.

Haffar, I. E. L., Blanc, M. \& Thorel, L., (2017). Impact of pile installation method on the axial capacity in sand. Géotechnique Letters, 7(3), pp.260-265. http://dx.doi.org/10.1680/jgele.17.00036.

Heins, E., Bienen, B., Randolph, M. F., \& Grabe, J. (2018). Effect of installation method on static and dynamic load test response for piles in sand. International Journal of Physical Modelling in Geotechnics, 1-23. http://dx.doi.org/10.1680/jphmg.18.00028. 
611 Henke, S. \& Bienen, B., (2013). Investigation of the influence of the installation method on the soil plugging behaviour of a tubular pile. ICPMG2014 - Physical Modelling in Geotechnics, pp.681-687. http://dx.doi.org/10.1201/b16200-94.

614 Henke, S. \& Grabe, J., (2008). Numerical investigation of soil plugging inside openended piles with respect to the installation method. Acta Geotechnica, 3(3), pp.215223. http://dx.doi.org/10.1007/s11440-008-0079-7.

Klinkvort, R.T., 2012. Centrifuge modelling of drained lateral pile-soil response (Doctoral dissertation, Technical University of Denmark).

Klinkvort, R. \& Hededal, O., 2010. Centrifuge modelling of offshore monopile foundation. Frontiers in Offshore Geotechnics II, pp.581-586. http://dx.doi.org/10.1201/b10132-78.

Labenski, J., Moormann, C., Aschrafi, J., \& Bienen, B. (2016). Simulation of the plug inside open steel pipe piles with regards to different installation methods. Proceedings of 13 th

Baltic

Sea

Geotechnical

Conference. http://dx.doi.org/10.3846/13bsgc.2016.034.

Leblanc, C., Houlsby, G.T. \& Byrne, B.W., (2010). Response of stiff piles in sand to long-term cyclic lateral loading. Géotechnique, 60(2), pp.79_ 90.http://dx.doi.org/10.1680/geot.7.00196.

Lehane, B.M., Schneider, J.A. \& Xu, X., (2005). A review of design methods for offshore driven piles in siliceous sand. UWA Report GEO, 5358.

Mahutka, K.P., König, F. \& Grabe, J., (2006), March. Numerical modelling of pile jacking, driving and vibratory driving. In Proceedings of International Conference on Numerical Simulation of Construction Processes in Geotechnical Engineering for Urban Environment (NSC06), Bochum, ed. T. Triantafyllidis, Balkema, Rotterdam pp. 235-246.

Matlock, H., (1970). Correlation for design of laterally loaded piles in soft clay. Offshore Technology Conference. http://dx.doi.org/10.4043/1204-ms.

Pucker, T., Bienen, B. \& Henke, S., 2013. CPT based prediction of foundation penetration in siliceous sand. Applied Ocean Research, 41, pp.9-18. http://dx.doi.org/10.1016/j.apor.2013.01.005.

Randolph, M.F. \& Gaudin, C. (2017). Genesis of the National Geotechnical Centrifuge Facility - a 30 year perspective. Australian Geomechanics, 52(2), 1-17. 
643 Reese, L.C., Cox, W.R. \& Koop, F.D., (1974). Analysis of laterally loaded piles in sand.

644 Offshore Technology Conference. http://dx.doi.org/10.4043/2080-ms.

645 Schneider, J. \& Lehane, B., (2006). Effects of width for square centrifuge displacement 646 piles in sand. Physical Modelling in Geotechnics.

$647 \quad$ http://dx.doi.org/10.1201/noe0415415866.ch125.

648 Tran, M.N., 2005. Installation of suction caissons in dense sand and the influence of silt 649 and cemented layers (Doctoral dissertation, The University of Sydney).

650 Verdure, L., Garnier, J. \& Levacher, D., (2003). Lateral cyclic loading of single piles in 651 sand. International Journal of Physical Modelling in Geotechnics, 3(3), pp.17-28. 652 http://dx.doi.org/10.1680/ijpmg.2003.030303.

653 Zdravković, L., Taborda, D.M.G., Potts, D.M., Jardine, R.J., Sideri, M., Schroeder, F.C., 654 Byrne, B.W., McAdam, R., Burd, H.J., Houlsby, G.T. \& Martin, C.M., (2015). 655 Numerical modelling of large diameter piles under lateral loading for offshore wind 656 applications. Frontiers in Offshore Geotechnics III, pp.759-764. 657 http://dx.doi.org/10.1201/b18442-105.

658 
Table 1 Properties of very fine UWA silica sand (Pucker et al, 2013)

\begin{tabular}{lll}
\hline Parameter & Value & Description \\
\hline $\mathrm{d}_{50}$ & 0.19 & Mean particle size $(\mathrm{mm})$ \\
$\mathrm{U}$ & 1.9 & index of uniformity \\
$\gamma_{\mathrm{d} \text { min }}$ & 14.9 & minimum dry density $\left(\mathrm{kN} / \mathrm{m}^{3}\right)$ \\
$\gamma_{\mathrm{d} \max }$ & 18.0 & maximum dry density $\left(\mathrm{kN} / \mathrm{m}^{3}\right)$ \\
\hline
\end{tabular}

660 
661

Table 2: Details of tests conducted

\begin{tabular}{clc}
\hline Test No. & Installation phase & Lateral load phase \\
\hline 1 & jacking at $100 \mathrm{~g}$ & monotonic push over at $100 \mathrm{~g}$ \\
2 & jacking at $1 \mathrm{~g}$ & monotonic push over at $100 \mathrm{~g}$ \\
3 & impact driving at $100 \mathrm{~g}$ & monotonic push over at $100 \mathrm{~g}$ \\
\hline
\end{tabular}

662 Notes:

663 1. Sample relative density: $38 \pm 4 \%$ after Schneider and Lehane (2006) , Average unit $664 \quad$ weight $\gamma=15.0 \mathrm{kN} / \mathrm{m}^{3}$;

665 2. Achieved embedment length was $3.1 \mathrm{D}_{\text {pile }}$ in Test 1 , which was kept the same for $666 \quad$ tests 2 and 3;

667 3. Load eccentricity is $3.8 \mathrm{D}_{\text {pile. }}$

668 
669

Table 3 Lateral bearing capacity

\begin{tabular}{clc}
\hline Test No. & Installation method & $\begin{array}{c}\text { Capacity mobilised at } \mathrm{y}_{0} / \mathrm{D}_{\text {pile }}=0.1 \\
\text { Normalised values } \mathrm{H} /\left(\gamma \mathrm{D}_{\text {pile }}\right)^{3}[-]\end{array}$ \\
\hline 1 & jacking at $100 \mathrm{~g}$ & 2.9 \\
2 & jacking at $1 \mathrm{~g}$ & 2.6 \\
3 & impact driving at $100 \mathrm{~g}$ & 3.4 \\
\hline
\end{tabular}

670 
671

Table 4 Lateral stiffness

\begin{tabular}{clcc}
\hline Test No. & Installation method & $\begin{array}{c}\text { Initial stiffness } \\
\text { Normalised value } \mathrm{H} /\left(\mathrm{y} 0 \gamma \mathrm{D}_{\text {pile }}{ }^{2}\right)[-]\end{array}$ & $\begin{array}{c}\text { Secant stiffness } \\
\end{array}$ \\
& jacking at 100g & 354.4 & 29.1 \\
2 & jacking at $1 \mathrm{~g}$ & 233.8 & 26.3 \\
3 & impact driving at 100g & 567.3 & 34.2 \\
\hline
\end{tabular}

672 
673 Figure 1. Connection between the pile driver and the pile tip (a) rigid connection; (b)

674 modified connection used in this study; (c) photo of connection details

675

676 Figure 2. Details of the lateral loading rig (a) side view; (b) view from below

677

678 Figure 3. Experimental arrangement (a) schematic; (b) photo

679

680 Figure 4. Side view of test layout (post installation)

681

682 Figure 5. Details of the model monopile

683

684 Figure 6. CPT profiles

685

686 Figure 7. Penetration resistance for jacked installation (1g and Ng)

687

688 Figure 8. Cumulative hammer blow count versus the penetration depth; (b) Transient peak 689 impact driving force

690

691 Figure 9. Comparison of load displacement curve derived from different beam theories 692

693 Figure 10. Load displacement curve 694 
695 Figure 1

(a)

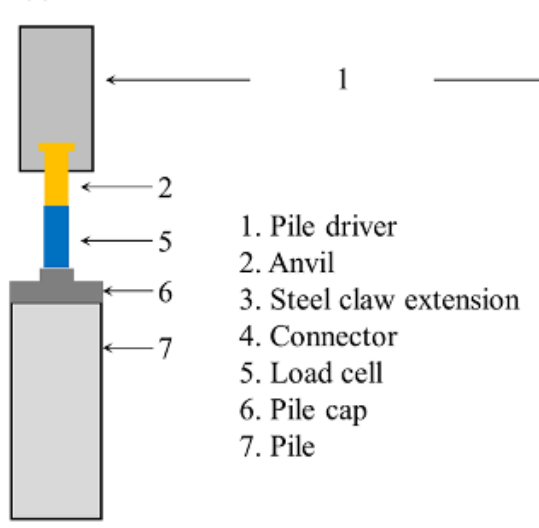

(b)

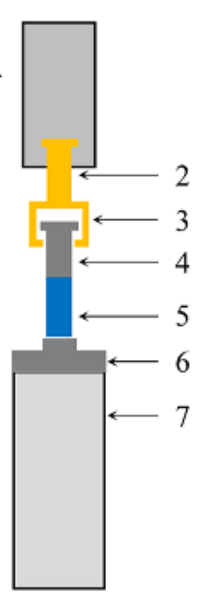

(c)

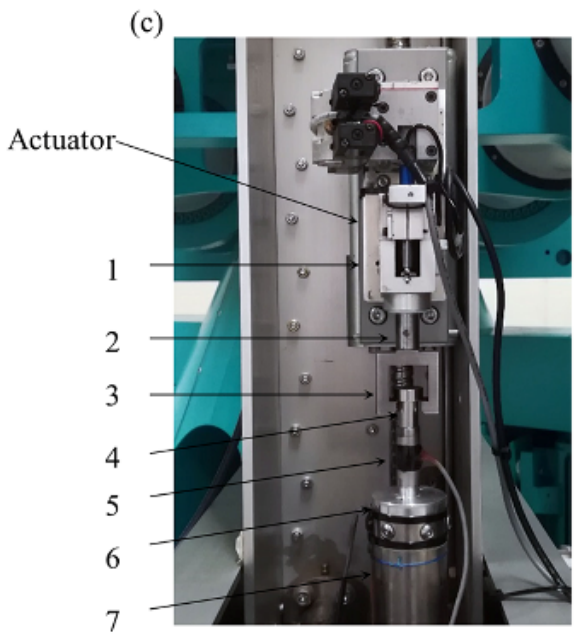


698 Figure 2

(a)

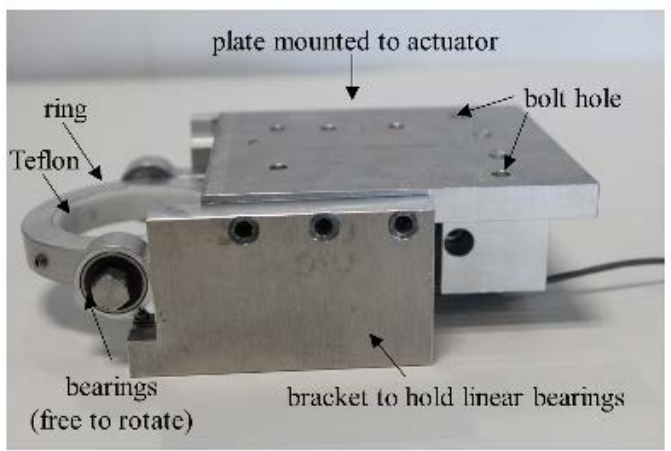

(b)

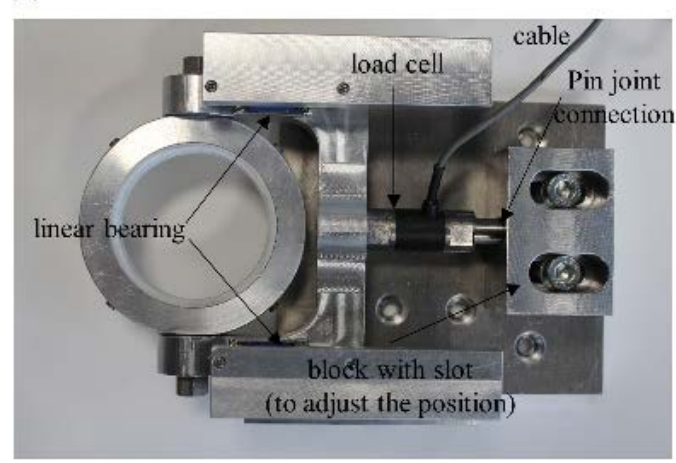

699

700 
Figure 3

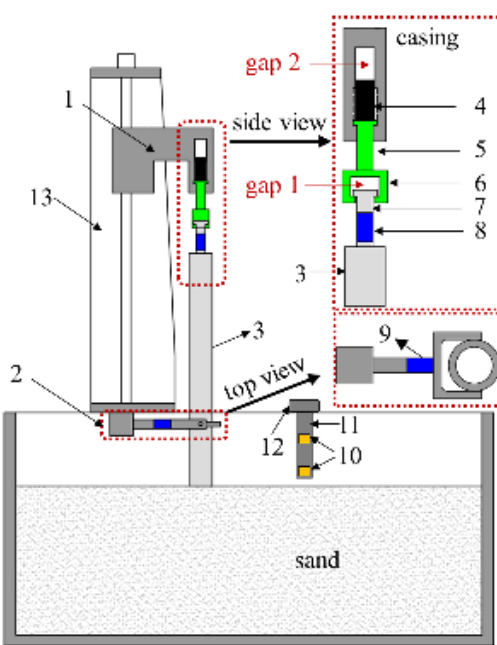

(b)

1. Miniature pile drive

2. Lateral loading rig

3. Pile

4. Ram (dead weight)

5. Steel anvil

6. Steel claw

7. Conncetor

8. Load cell (vertical)

9. Load cell (horizontal)

10. Top and bottom laser

11. Laser bracket

12. Cross beam

13. Actuator tower

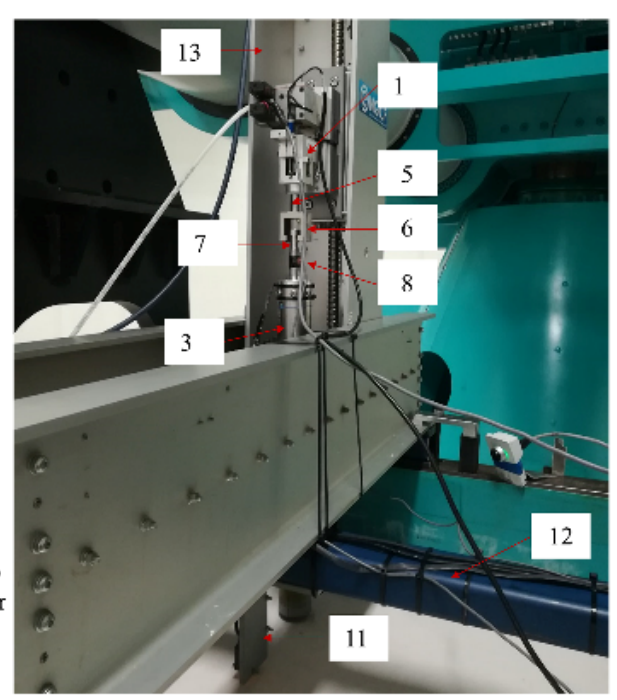


$704 \quad$ Figure 4

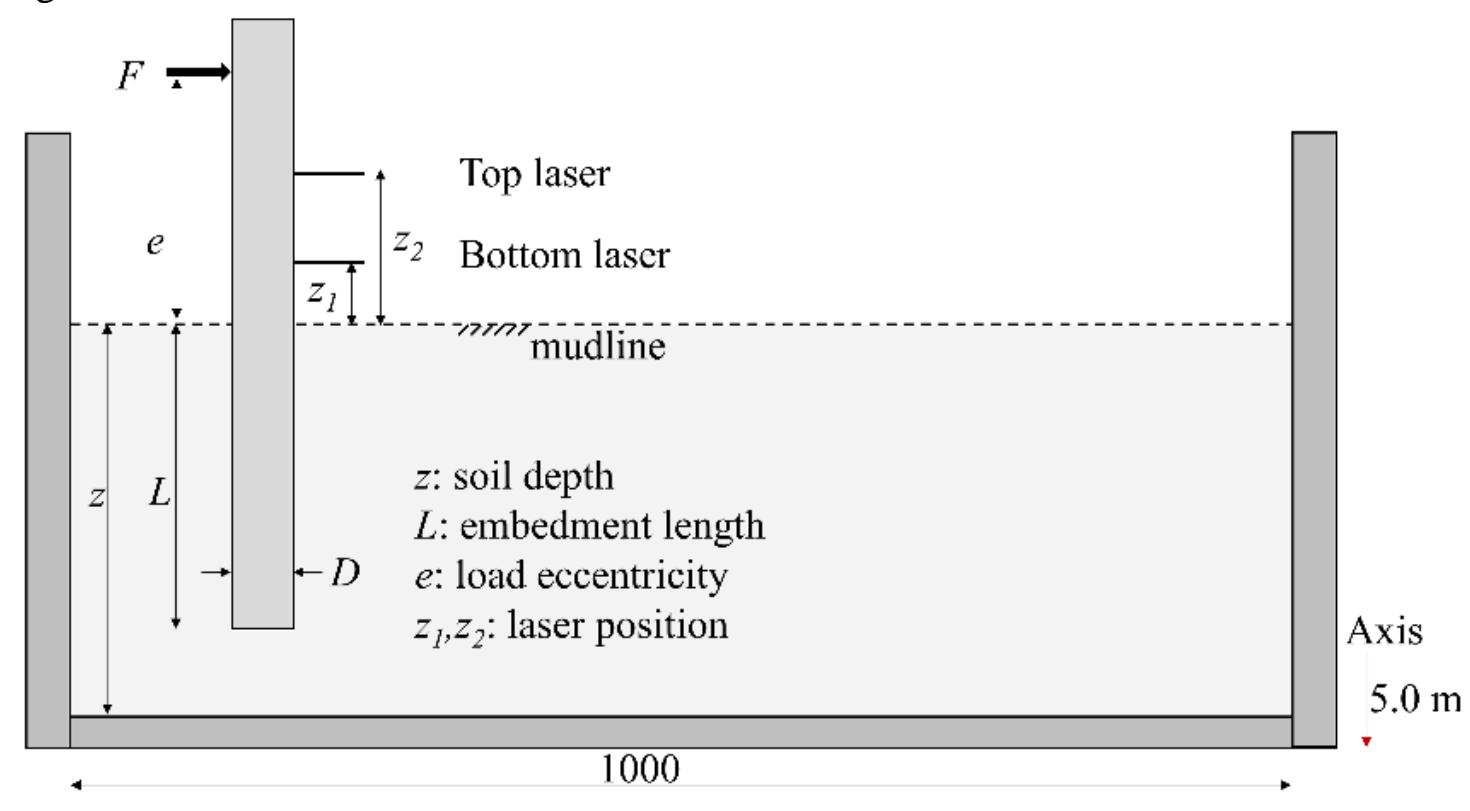


Figure 5

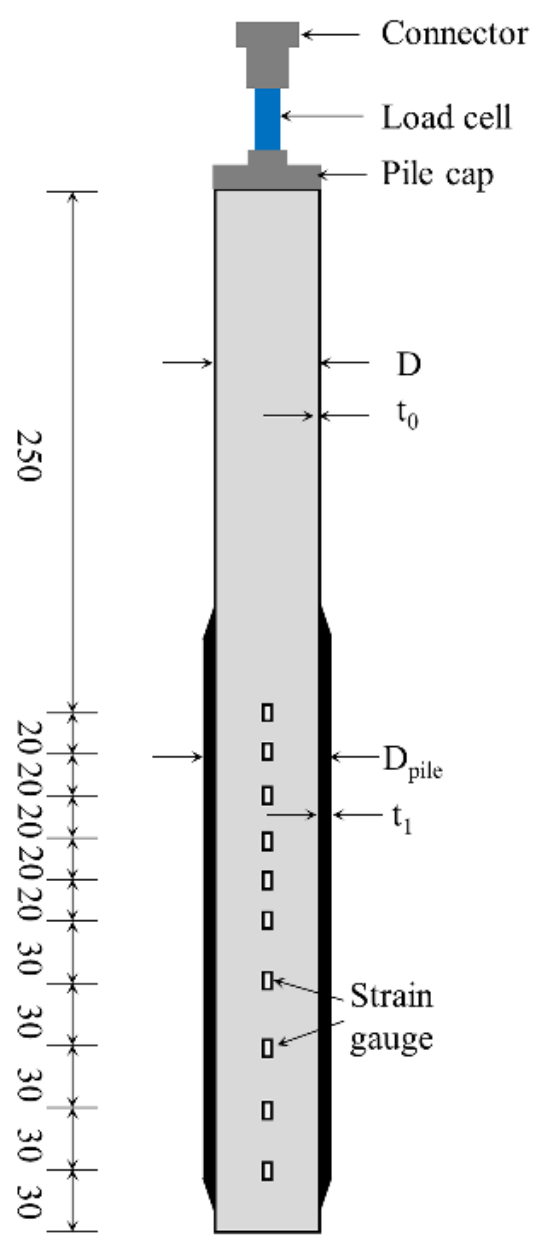

D steel pile outer diameter, $50.0 \mathrm{~mm}$

$\mathrm{t}_{0}$ steel pile wall thickness, $1.0 \mathrm{~mm}$

$\mathrm{t}_{1}$ Epoxy coating thickness, $1.1 \mathrm{~mm}$

$\mathrm{D}_{\text {pile }}$ overall pile diameter, $52.2 \mathrm{~mm}$

$\mathrm{T}$ overall wall thickness, $2.1 \mathrm{~mm}$

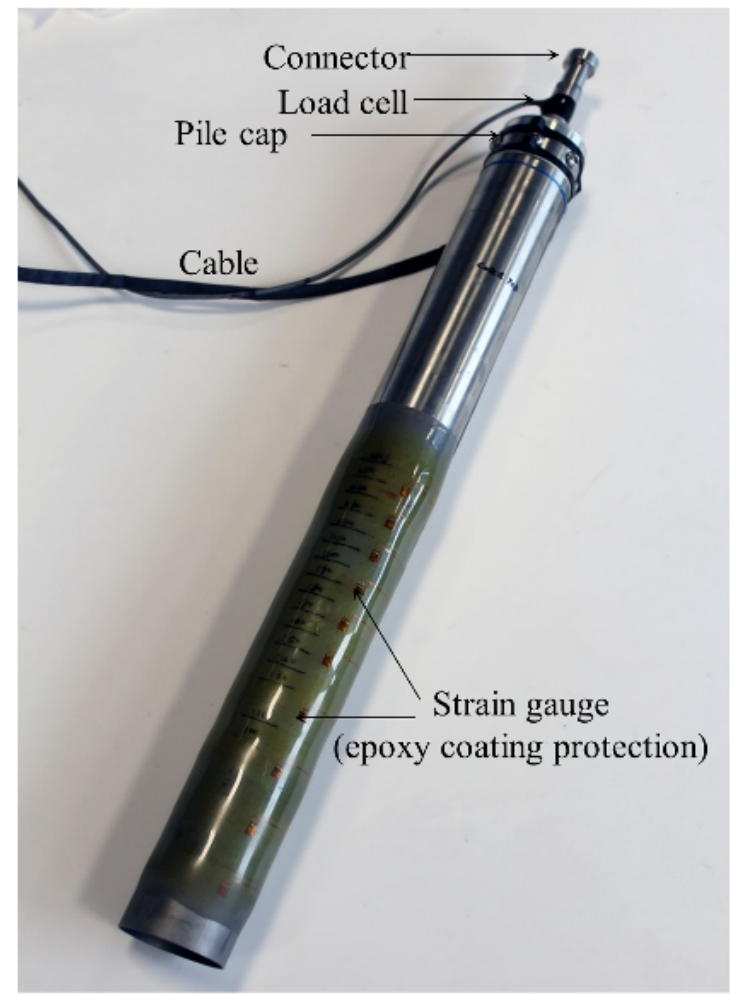


$710 \quad$ Figure 6

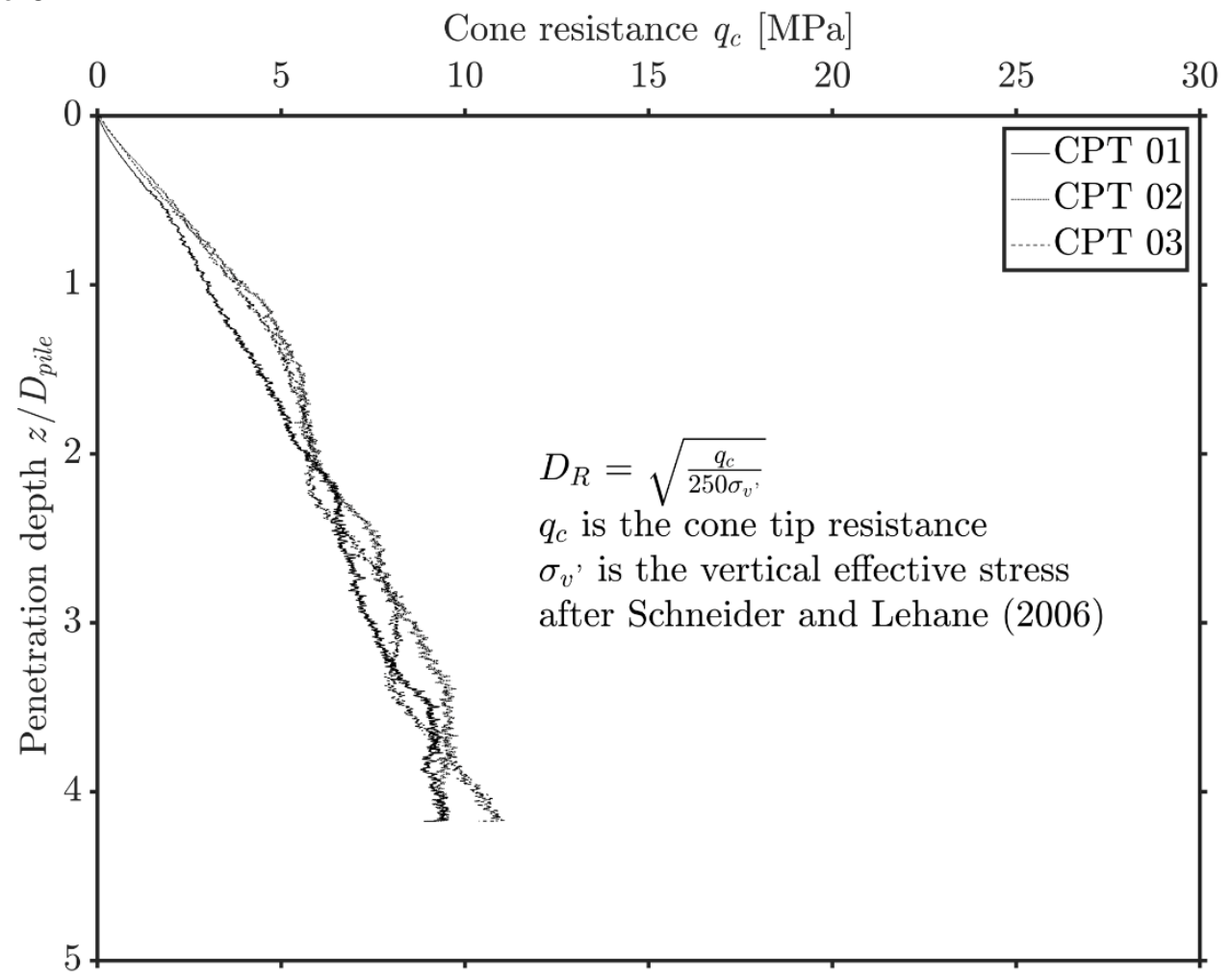


$713 \quad$ Figure 7

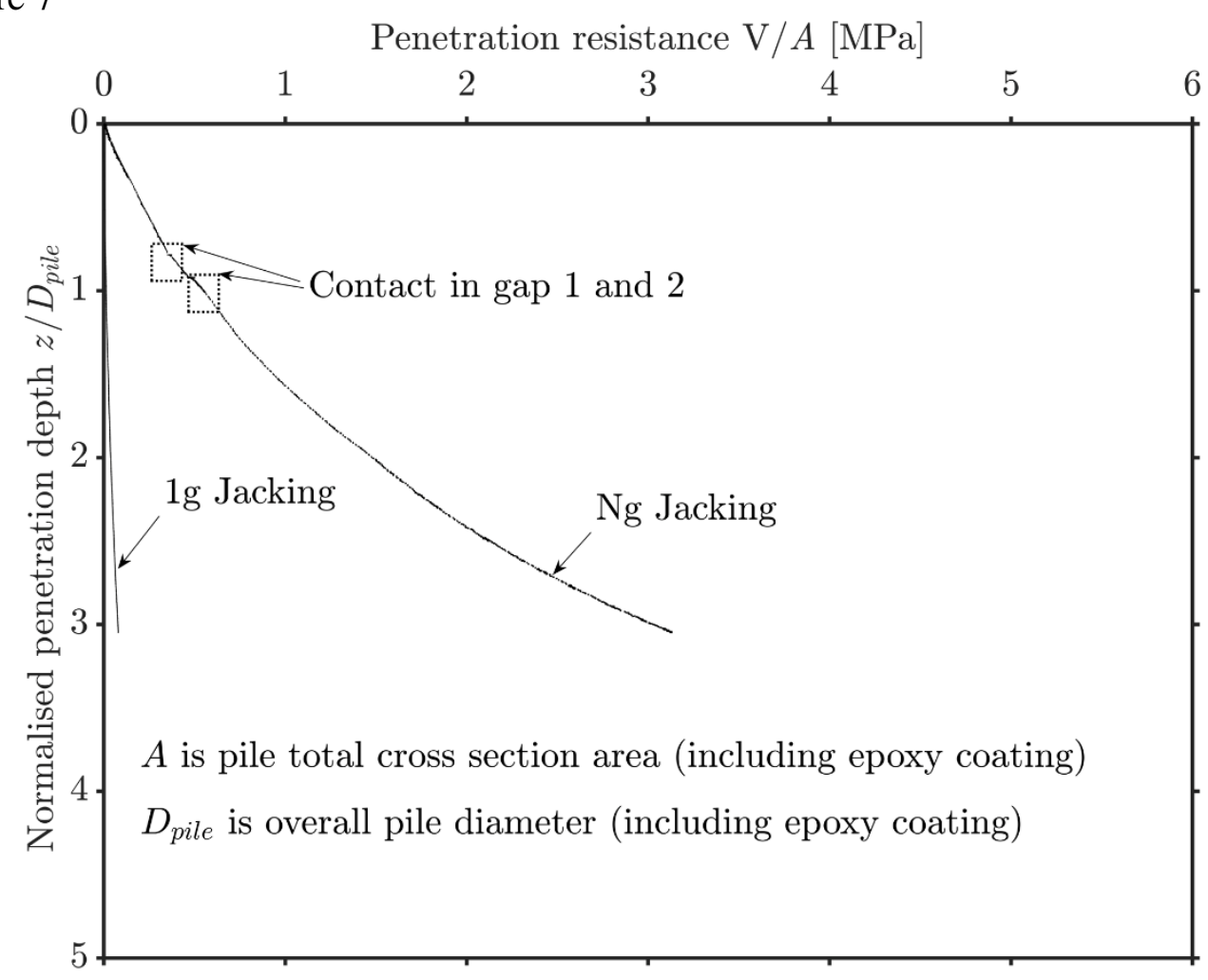




\section{Figure 8}

717

(a)

Accumulated number of blows

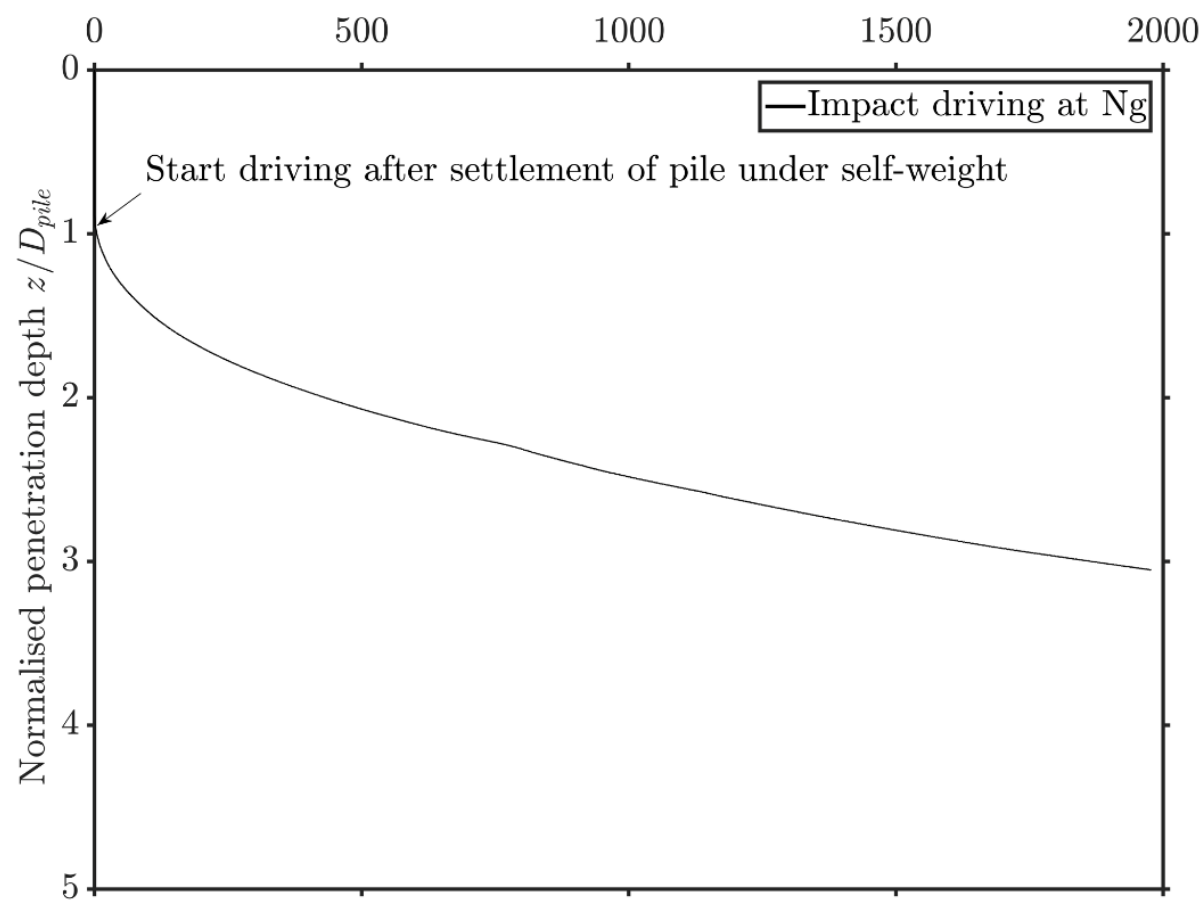

(b)

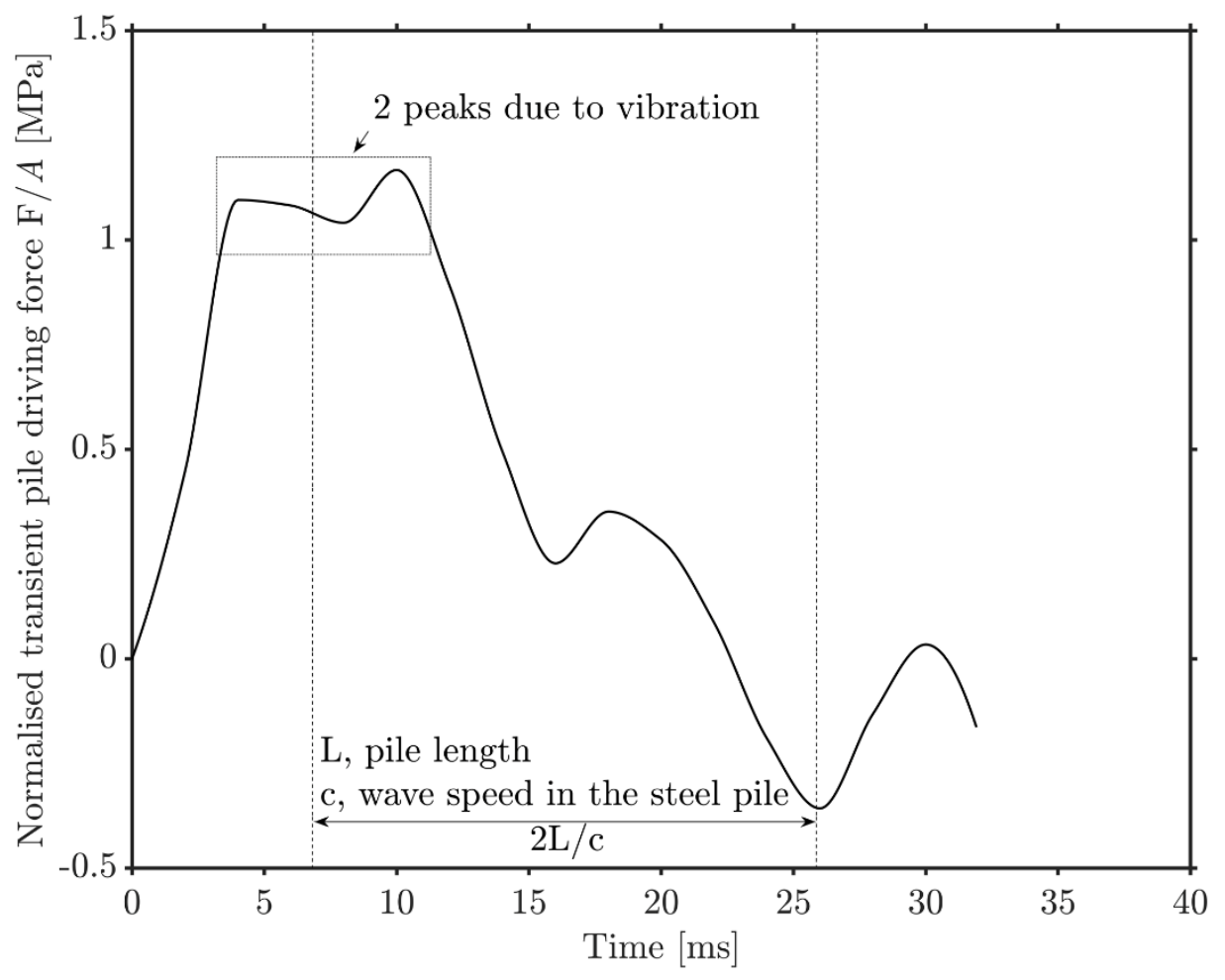


Figure 9

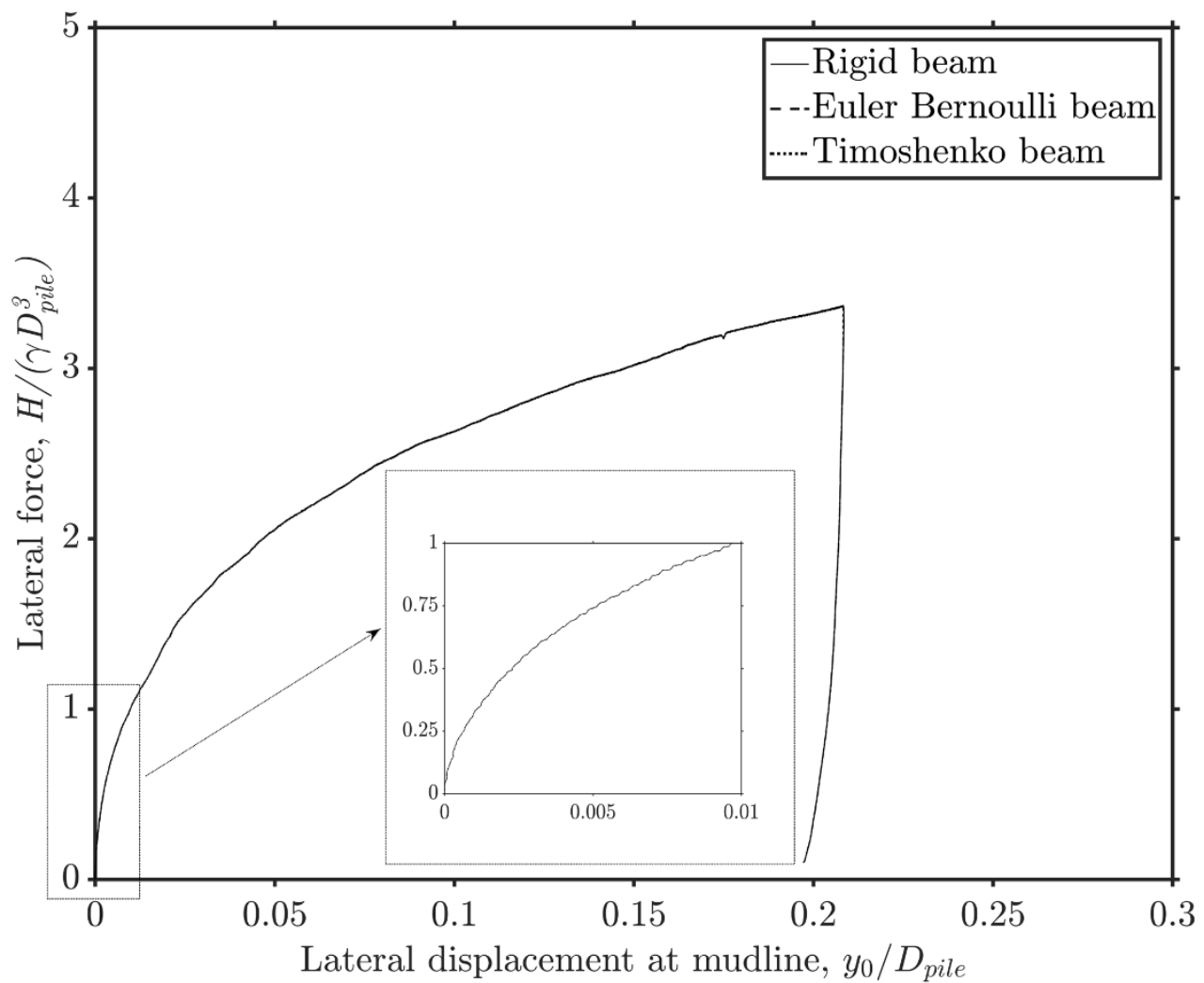


Figure 10

726

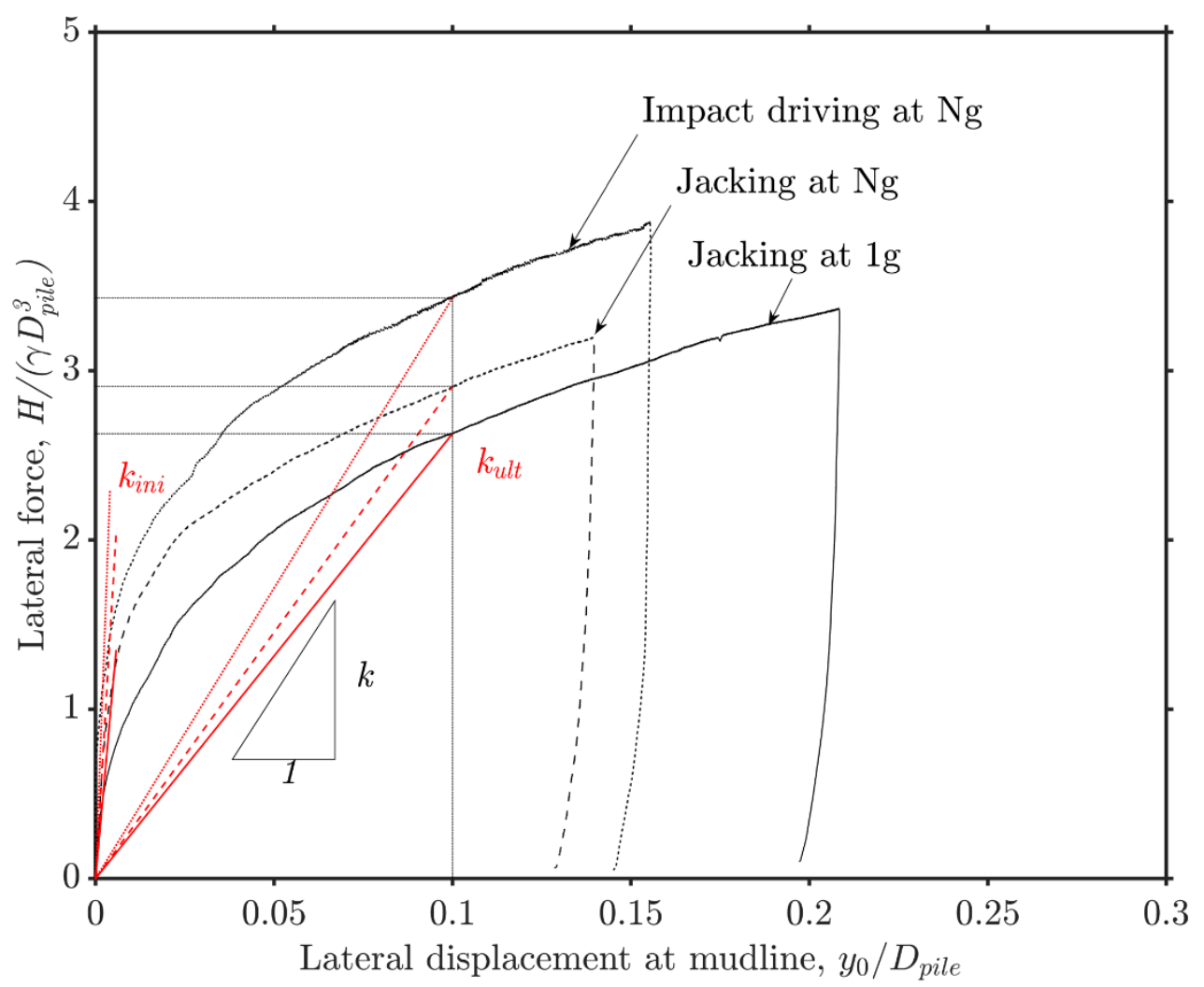

727

728

729

730 